\title{
PENGARUH PERENDAMAN KERANG DARAH (Anadara granosa) DENGAN PERASAN JERUK NIPIS TERHADAP KADAR MERKURI (Hg) DAN KADMIUM (Cd)
}

\author{
Dheasy Herawati ${ }^{1)}$, Soedaryo ${ }^{2)}$ \\ ${ }^{1), 2)}$ Dosen Fakultas Ilmu Kesehatan, UMAHA, Sidoarjo \\ Email : dheasy15@gmail.com
}

\begin{abstract}
This study aimed to determine the effect of soaking blood cockle with lemon on levels of mercury and cadmium. The blood cockle can accumulate heavy metals contained in the water, so it could endanger public health. One of the efforts to reduce levels of heavy metals is with the addition of lime (Citrus aurantifolia), because it contains citric acid that can bind heavy metals. Levels of mercury and cadmium of blood cockle in the blood were measured with AAS before and after soaking with lime juice for 10, 20 and 30 minutes. The results showed that decreased levels of mercury and cadmium in the blood cockle.
\end{abstract}

Keywords: Blood cockle, Lime, Mercury, Cadmium

\section{PENDAHULUAN}

Pencemaran merupakan salah satu permasalahan yang besar. Adanya masukan limbah ke dalam perairan dapat mengakibatkan perubahan kualitas perairan baik secara fisik maupun kimia. Zat pencemar yang menurunkan kualitas perairan itu diantaranya adalah logam berat yang berbahaya. Di antara semua unsur logam berat, $\mathrm{Hg}$ menduduki urutan pertama dalam sifat racun. Diikuti oleh logam berat lainnya yaitu $\mathrm{Cd}, \mathrm{Ag}, \mathrm{Ni}, \mathrm{Pb}$, As, Cr, Sn, dan Zn (Darmono, 2001).

Tingkat toksisitas $\mathrm{Hg}$ dapat dilihat dari nilai PTWI (Privisional Tolerable Weekly Intake) sebesar $0,005 \mathrm{mg} / \mathrm{kg} \mathrm{BB}$ Sebagai merkuri total dan $0,0016 \mathrm{~g} / \mathrm{kg} \mathrm{BB}$ sebagai metilmerkuri (Alsuhendra, 2013).
Sementara itu, nilai LD50 dari Cd adalah $225 \mathrm{mg} / \mathrm{kg}$ dan nilai PTWI (Provisional Tolerated Weekly Intake) sebesar $0.007 \mathrm{mg} / \mathrm{kg}$ BB. Diperkirakan dosis mematikan akut dari $\mathrm{Cd}$ adalah sekitar $500 \mathrm{mg} / \mathrm{kg}$ untuk orang dewasa. Efek mematikan dari dosis tersebut akan terlihat apabila Cd diserap sebanyak 0.043 $\mathrm{mg} / \mathrm{kg}$ per hari (Darmono, 2001).

Logam-logam berat yang masuk dalam perairan akan mengalami proses pengendapan dan terakumulasi dalam sedimen, kemudian terakumulasi terutama di dalam tubuh biota laut yang menetap dan logam berat akan terkonsentrasi ke dalam tubuh makhluk hidup dengan proses bioakumulasi dan biomagnifikasi melalui beberapa jalan, yaitu melalui saluran pernapasan, saluran makanan dan melalui 
kulit. Kelompok organisme yang mampu mengakumulasi logam berat adalah bivalvia. Kemampuan tersebut menjadikan bivalvia menjadi bioindikator suatu perairan (Dahuri et al. 1996 dalam Putri, 2010).

Kerang darah merupakan salah satu biota laut yang dapat digunakan sebagai bioindikator tingkat pencemaran air laut. Sifat kerang yang menetap di suatu tempat karena pergerakan yang lambat, dan bersifat filter feeder non selective, yaitu menyaring air untuk mendapatkan makanan, menyebabkan kerang rentan terkena bahan polusi air, terutama logam berat yang bersifat akumulatif dalam tubuh kerang (Darmono, 2001). Dalam pertumbuhannya, kerang darah dapat mengakumulasi logam berat dalam tubuhnya jika hidup pada perairan yang terkontaminasi logam berat (Suwignyo, 2005).

Upaya untuk mengurangi konsentrasi merkuri dan cadmium pada kerang dapat dilakukan dengan perasan jeruk nipis karena terdapat asam sitrat yang berfungsi sebagai sekuestran, yaitu zat yang dapat mengikat logam pada makanan dan menyebabkan logam kehilangan sifat ionnya sehingga dapat mengurangi daya toksisitas logam tersebut (Suwignyo, 2005).

Berdasarkan uraian di atas, perlu dilakukan penelitian tentang pengaruh perendaman kerang darah dengan perasan jeruk nipis terhadap kadar merkuri dan cadmium, sehingga dapat memberikan hasil yang terbaik.

\section{METODOLOGI PENELITIAN}

Data dianalisa secara kuantitatif dan disajikan dalam bentuk kurva standar dan tampilan berbentuk tabulasi (tabel) data.

\section{Tempat Penelitian}

Penelitian ini dilaksanakan di laboratorium penelitian Balai Riset dan Standarisasi Surabaya (BARISTAN).

\section{Alat dan Bahan Penelitian}

Alat penelitian yang digunakan adalah pipet ukut, spektrofotometer, beaker glass, gelas ukur. Bahan penelitian adalah Kerang Darah (Anadara granosa) yang diambil dari pasar Kenjeran Surabaya kemudian dipisahkan daging kerang dari cangkangnya. Sebagian diperiksa tanpa perendaman. Sebagian lagi direndam dalam air tanpa dan dengan perasan jeruk nipis selama 10, 20 dan 30 menit masingmasing sebanyak 100 gram.

\section{Cara Kerja \\ Pembuatan kurva baku Merkuri}

Untuk blanko sebanyak $200 \mathrm{ml}$ air bebas mineral dimasukkan ke dalam labu pembangkit uap merkuri, ditambahkan 5 ml larutan $\mathrm{SnCl}_{2}$ 10\%. Absorban dinolkan pada $\lambda 253,7 \mathrm{~nm}$. Dilanjutkan dengan pengukuran larutan standar merkuri dengan menambahkan $1,0 \mathrm{ml} ; 1,5 \mathrm{ml}$ dan 2,0 $\mathrm{ml}$ dari larutan baku merkuri 0,5 ppm Dihitung persamaan regresi dan koefisien korelasi absorban terhadap kadar Hg.

\section{Pembuatan Kurva baku Kadmium}

1. Dipipet $10 \mathrm{ml}$ stok Kadmium 1000 ppm masukkan labu takar $100 \mathrm{ml}$ dan tepatkan dengan aquades sampai tanda batas. 
2. Larutan Kadmium 100 ppm berturut turut $0.2 \mathrm{ml}, 0.5 \mathrm{ml}, 1 \mathrm{ml}$, dan $3 \mathrm{ml}$. Masing - masing masukkan kedalam erlenmeyer yang telah berisi $100 \mathrm{ml}$ air.

3. Dipipet larutan standart Cd 0,2;0,5;1,0 dan 3,0 ppm.Masing - masing diukur absorbansinya dengan spektrofotometer serapan atom dengan panjang gelombang 228,8 nm. Dengan blanko berisi aquades sebanyak $100 \mathrm{ml}$.

4. Plot kurva standart Kadmium antara resapan terhadap konsentrasi dan tentukan regresi liniernya.

\section{Penetapan Kadar Hg (SNI 19-2896-1992)}

1. Sampel sebanyak 5,0 gram didestruksi selama 1 jam dengan penambahan 25 $\mathrm{ml} \mathrm{H}_{2} \mathrm{SO}_{4} 18 \mathrm{~N}, 20 \mathrm{ml} \mathrm{HNO}_{3} 7 \mathrm{~N}$ dan $1,0 \mathrm{ml}$ Na-molibdat $2 \%$ serta batu didih. Kemudian didinginkan selama 15 menit, ditambahkan $20 \mathrm{ml}$ campuran $\mathrm{HNO}_{3}$ dan $\mathrm{HClO}_{4}(1: 1)$ melalui bagian atas dari pendingin.

2. Dilanjutkan pemanasan pada suhu tinggi sampai terbentuk uap putih dan lanjutkan pemanasan selama 10 menit, kemudian dinginkan.

3. Dengan hati-hati ditambahkan $10 \mathrm{ml}$ air melalui pendingin sambil labu digoyang-goyangkan, didihkan lagi selama 10 menit, kemudian dinginkan.

4. Secara kuantitatif pindahkan larutan hasil destruksi ke dalam labu ukur 200 ml, encerkan dengan air sampai tanda garis.

5. Sampel dimasukkan ke dalam labu pembangkit uap merkuri, kemudian tambahkan $\mathrm{SnCl}_{2} 10 \%$ sebanyak $5 \mathrm{ml}$.

6. Absorbansi sampel dibaca pada Spektrofotometer Serapan Atom dengan panjang gelombang 253,7 $\mathrm{nm}$.

\section{Penetapan Kadar Kadmium (SNI-01- 2891 - 1992)}

1. Ditimbang 5 gram sampel dalam cawan porselenyang sudah di oven terlebih. Sampel dipanaskan diatas hot plate sampai bewarna kehitaman \pm 2 jam .

2. Cawan dimasukkan ke dalam tanur yang telah diatur suhunya $550^{\circ} \mathrm{C}$, dibiarkan sampai sampel bewarna abu abu.

3. Cawan dikeluarkan dari dalam tanur dan dibiarkan dingin. Abu dilarutkan dalam $25 \mathrm{ml} \mathrm{HNO}_{3} 1 \mathrm{~N}$. Lalu saring sampel menggunakan kertas saring Whatman 42 kedalam labu ukur $100 \mathrm{ml}$.

4. Cawan dan kertas saring dibilas beberapa kali tiap kali dengan $25 \mathrm{ml}$ aquades pada labu takar $100 \mathrm{ml}$. Ditambahkan aquades sampai tanda batas.

5. Sampel dibaca pada Spektrofotometer Serapan Atom Shimadzu AA 6200 pada panjang gelombang $228,8 \mathrm{~nm}$.

\section{HASIL DAN PEMBAHASAN}

Hasil penelitian dan pemeriksaan kadar merkuri dan kadmium pada sampel kerang darah dapat dilihat pada tabel 1.

Dari kurva baku merkuri didapatkan persamaan regresi $\mathrm{Y}=0,1043 \mathrm{X}+0,0009$ dengan $\mathrm{R}^{2}=0,9963$ sedangkan kurva baku kadmium $\mathrm{Y}=0,3475 \mathrm{X}+0,0004$ dengan $\mathrm{R}^{2}=1$.

Pada Tabel.1 dapat diketahui bahwa terjadi penurunan kadar merkuri dan kadmium baik dengan atau tanpa penambahan jeruk nipis. Perendaman menggunakan air biasa dapat menurunkan kadar merkuri dan kadmium sebanding dengan lama perendaman, walaupun tidak 
seefektif dengan jeruk nipis. Menurut Murtini et al. 2008, bahwa perendaman dalam air saja sudah menurunkan logam berat pada daging kerang hijau sebanyak $50-60 \%$. Penurunan kandungan $\mathrm{Hg}$ dan Cd pada perendaman dalam air diduga merupakan akibat terlepasnya ion logam dari struktur protein kerang yang kemudian terlarut keluar dari daging kerang sebagai upaya penyeimbang konsentrasi dalam daging kerang.

Kemampuan larutan jeruk nipis untuk menurunkan kadar $\mathrm{Hg}$ dan $\mathrm{Cd}$ pada kerang darah disebabkan oleh adanya asam sitrat yang terkandung dalam jeruk nipis.

Tabel 1. Hasil Penetapan Kadar Hg dan Cd pada kerang darah dengan dan tanpa Perendaman dengan jeruk nipis

\begin{tabular}{|c|c|c|c|c|}
\hline \multirow[t]{3}{*}{ No } & \multirow[t]{3}{*}{ Perlakuan } & \multicolumn{3}{|c|}{ Kadar Hg (mg/kg) } \\
\hline & & \multirow{2}{*}{$\begin{array}{c}\text { Tanpa } \\
\text { Perendaman }\end{array}$} & \multicolumn{2}{|c|}{ Perendaman } \\
\hline & & & tanpa jeruk & dengan jeruk \\
\hline 1. & Tanpa perlakuan & 0,0047 & - & - \\
\hline 2. & Perendaman 10 menit & - & 0,0032 & 0,0017 \\
\hline 3. & Perendaman 20 menit & - & 0,0024 & 0,0015 \\
\hline 4. & Perendaman 30 menit & - & 0,0014 & 0,0012 \\
\hline & Rata - Rata & 0,0047 & 0,0028 & 0,0016 \\
\hline \multirow[t]{3}{*}{ No } & Perlakuan & \multicolumn{3}{|c|}{ Kadar Cd (mg/kg) } \\
\hline & & \multirow{2}{*}{$\begin{array}{c}\text { Tanpa } \\
\text { Perendaman }\end{array}$} & \multicolumn{2}{|c|}{ Perendaman } \\
\hline & & & tanpa jeruk & dengan jeruk \\
\hline 1. & Tanpa perlakuan & 0,17 & - & - \\
\hline & Perendaman 10 menit & - & 0,15 & 0,053 \\
\hline & Perendaman 20 menit & - & 0,13 & 0,090 \\
\hline & Perendaman 30 menit & - & 0,11 & 0,046 \\
\hline & Rata - Rata & 0,17 & 0,13 & 0,063 \\
\hline
\end{tabular}


Asam sitrat adalah salah satu zat sekuestran (zat pengikat logam). Asam sitrat memiliki rumus kimia $\mathrm{CH}_{2} \mathrm{COOH}-\mathrm{COHCOOH}-\mathrm{CH}_{2} \mathrm{COOH}$ $\left(\mathrm{C}_{6} \mathrm{H}_{8} \mathrm{O}_{7}\right)$. Gugus fungsional $-\mathrm{OH}$ dan $\mathrm{COOH}$ pada asam sitrat menyebabkan ion sitrat dapat bereaksi dengan ion logam membentuk garam sitrat. Menurut Rusli, 2010, ion sitrat akan mengikat logam sehingga dapat menghilangkan ion logam yang terakumulasi pada kerang sebagai kompleks sitrat. Semakin tinggi konsentrasi suatu larutan, semakin cepat larutan tersebut untuk bereaksi dengan senyawa lain. Begitu juga dengan lama perendaman. Semakin lama waktu suatu zat berinteraksi dengan senyawa lain, maka semakin cepat reaksi antara asam sitrat dengan logam. Hal ini sejalan dengan penelitian Buwono, 2005 yang menyatakan bahwa waktu perendaman dengan larutan asam berpengaruh nyata terhadap penurunan logam pada kerang.

\section{KESIMPULAN}

Dari penelitian didapatkan hasil bahwa perendaman dengan jeruk nipis dapat menurunkan kadar merkuri dan kadmium sebanding dengan lama perendaman.

\section{UCAPAN TERIMAKASIH}

Penulis mengucapkan terimakasih kepada seluruh tim peneliti dan staf laboratorium kimia yang telah banyak membantu selama proses penelitian ini berlangsung hingga selesai.

\section{DAFTAR PUSTAKA}

Astarini, Niluh Putu Febrina, dkk. 2010. Minyak Atsiri dari Kulit Buah Citrus grandis, Citrus aurantium (L.) dan Citrus aurantifolia (RUTACEAE) Sebagai Senyawa Antibakteri dan Insektisida. Prosiding KIMIA FMIPA - ITS. Surabaya.

Darmono. 2001. Lingkungan Hidup dan Pencemaran (Hubungannya dengan Toksikologi Senyawa Logam). Universitas Indonesia Press. Jakarta.

Hariana, Drs. H. Arief. 2006. Tumbuhan Obat dan Khasiatnya. Penebar Swadaya Wisma Hijau. Jakarta.

Kompas. Kerang Pantura Tercemar Logam Berat,(http://www.goblue.or.id/keran g- pantura-tercemar-logam-berat-2), diakses 9 Desember 2014

Murtini, Jovita Tri. dkk. 2008. Pengaruh Waktu Perendaman Dan Konsentrasi Karboksimetil Kitosan Untuk Menurunkan Kandungan Logam Berat $\mathrm{Hg}$, Cd, Dan Pb Pada Kerang Hijau (Perna Viridis Linn.). Jurnal Pascapanen dan Bioteknologi Kelautan dan Perikanan. 3(1). Juni 2008.

Putri, Fitriana Intan. 2010. Kandungan Logam Berat $\mathrm{Hg}, \mathrm{Cd}$, dan $\mathrm{Pb}$ pada Kerang Darah (Anadara granosa) di Perairan Teluk Lada, Kabupaten Pandeglang, Banten. Fakultas Perikanan dan Ilmu Kelautan Institut Pertanian Bogor.

SNI (19 - 2896 - 1992). 1992. Cara Uji Cemaran Logam.

Sudarmadji, J. Mukono, dan Corie I. P. 2006. Toksikologi Logam Berat B3 Dan Dampaknya Terhadap 
Kesehatan. Jurnal Kesehatan

Lingkungan. 2(2) : 129 - 142.

Suprapti, N. H. 2008. Kandungan

Chromium pada Perairan, Sedimen dan Kerang Darah Anadara granosa L. di Wilayah Pantai Sekitar Muara
Sayung, Desa Morosari Kabupaten

Demak, Jawa Tengah. Jurusan Biologi FMIPA Universitas Diponegoro.

Suwignyo, S. 2005, Avertebrata Air, Penebar Swadaya, Jakarta. 